Issue no. $27 / 2018$

\title{
QUO VADIS EXTERNAL TRADE POLICY OF THE EUROPEAN UNION? EXPORTING ITS OWN VALUES OR BEING A POINT- GUARD WITHIN THE MULTILATERAL TRADING SYSTEM?
}

\author{
Prof. Dr. Elif UÇKAN DAĞDEMIR \\ Anadolu University, Faculty of Economics and Administrative Sciences, \\ Department of Economics, Eskişehir, Turkey. \\ euckan@anadolu.edu.tr
}

\section{DOI:10.24193/OJMNE.2018.27.09}

\begin{abstract}
European Union (EU) has a very distinctive status within the multilateral trading system and thus is found worthwhile to examine in many respects. It has been not only a prominent actor and a contributor of the multilateral trading system since the fundamentals of the system were set by the General Agreement on Tariffs and Trade (GATT) but also the chief executer of its own preferential trade relations compatible with the GATT and its successor, World Trade Organization (WTO). External trade policy has always been one of the privileged common policies of the EU and commitment to the multilateral trading system has constituted the core of it.

Upon the pending of the Doha Development Agenda (DDA), the EU has paved the way to deepen its trade relations with the other prominent actors of the multilateral trading system, namely the US, Canada, Japan and South Korea. These nouveau trade relations do not simply embrace trade but also investments, services, competition, etc. and thus favorably referred to new-age partnerships. Essentially, they constitute the pillars of the EU's new-born Trade for All Strategy.

Then, here come two inter-linked, substantial questions: Does the new external trade policy of the EU that is figured out by the Trade for All Strategy in general and the new-age partnerships in particular, compatible with the multilateral trading system? Would the EU by-pass the multilateral trading system and export its own values via new-age partnerships or be a point guard in the enhancement of the system? The aim of this paper is to make a contribution in responding these substantial questions.
\end{abstract}

Keywords: European Union and World Trade Organization; European Union and Multilateral Trading System; European Union and Doha Development Agenda; External Trade Policy of the European Union. 
Issue no. $27 / 2018$

\section{Introduction}

The multilateral trading system which had been figured out via GATT until 1995 and then via WTO, its successor, has been serving as a legitimate framework not only for the commodities and services trade but also for the trade related aspects of intellectual property rights. As of 2018, the WTO has 164 member countries from all over the world regardless of their diverse economic and political structures. The founding fathers of today's EU were the signatories of the GATT in 1947. Along with taking part within the multilateral trading system, the system itself paved the way to these six-founding fathers to establish an economic integration. Since then, the EU has been acting within the multilateral trading system on behalf of its member states. However, the EU has been going in full sail towards new-age partnerships within its new external trade policy since the deadlock of the DDA. Since newage partnership initiatives have gained momentum, the narratives on their compatibility with the multilateral trading system has become a contentious issue.

\section{EU within the Multilateral Trading System}

The EU has always been a unique example of an economic integration which has also been participating within the multilateral trading system as a prominent actor. The roots of the multilateral trading system were planted by the GATT. After experiencing two catastrophic world wars, the European countries together with the United States (US) decided to establish a new international economic order. This new international economic order was figured out at the Bretton Woods Conference in 1944. The participant countries decided to give financial and technical assistance to the vulnerable economies that exposed to the II. World War via reconstruction and development bank, known as the World Bank. The International Monetary Fund (IMF) was agreed to be the responsible institution for the wellfunctioning of the fixed exchange rate system. Moreover, an international organization which would be in charge of the multilateral trading system was decided to be established. Except for the International Trade Organization (ITO), the other international organizations were established to take part within this new international economic order. Upon the failure of the ITO initiative, the countries signed the GATT in 1947, referred to GATT 1947 so as to provide the rules of the multilateral trading system. 
Issue no. $27 / 2018$

The fundamental attitude of the GATT 1947 was to design the new international economic order based on free trade which depends on comparative advantage (Pischel, 2001: 105). The WTO which was established in 1995 and has taken the rules and the responsibilities of the multilateral trading system. The WTO not only covers the multilateral trading system on the commodities participated by GATT 1994 but also the General Agreement on Trade in Services (GATS) and the Agreement on Trade Related Aspects of Intellectual Property (TRIPS) as well as a Dispute Settlement Mechanism. However, it should be remarked that the WTO has not replaced the GATT as a whole because the GATT is still in force in laying the foundations of the multilateral trade in goods. Along with the establishment of the WTO, the GATT has become the strongest pillar of the WTO acknowledged as GATT 1994.

\subsection{Compliance of the EU with the Multilateral Trading System}

The multilateral trading system has been inducing and monitoring freer trade on the basis of non-discrimination, transparency, fair competition and encouragement of development and economic reform (WTOa). At a first glance, the establishment of the EU might be regarded as a contradiction with the non-discrimination principle of the multilateral trading system. Nevertheless, provided some conditions, the system enables exceptions for the establishment of free trade areas and customs unions. Article XXIV of the GATT 1947 allows the establishment of free trade areas and customs unions reaffirming that the aim of these kind of economic integrations should be to facilitate trade between the constituent territories and not to increase trade restrictions to the trade of other WTO members with such territories and that in their formation or enlargement the parties to them should to the greatest possible extent avoid creating adverse effects on the trade of other WTO member countries (WTOb).

According to Mortensen (2009: 83), multilateral trading system enabled the establishment of the EU in advance. The EU was the first economic integration experience within the multilateral trading system. It might be regarded that the multilateral trading system has given the EU a chance to play an important role within the system in shaping the trading rules. Moreover, it might be a good example of an economic integration compatible 
Issue no. $27 / 2018$

with the multilateral trading system and thus would encourage new economic integration initiatives.

\subsection{Status of the EU within the Multilateral Trading System}

The status of the EU within the multilateral trading system had been evolved. When the GATT was signed in 1947, the founding fathers of the EU were the sovereign contracting parties of the multilateral trading system. Nevertheless, over the time, the European Commission has acquired the status of a contracting party on behalf of the EU in trade issues (Bourgeois, 2000: 71). Since then, the multilateral trade negotiations have been conducted and finalized by the European Commission without the approval of the member states.

Along with the establishment of WTO in 1995, the EU became an individual member of the multilateral trading system. According to the Article XI of the Marrakesh Agreement which established the WTO, the contracting parties to GATT 1947, including the EU Member States and the EU would become original members of the WTO. Regarding the voting which is explained at the Article IX of the Marrakesh Agreement, each member of the WTO has one vote. On the other hand, the EU has a number of votes equal to the number of its Member States that are members of the WTO.

There have been criticisms on EU representation in the WTO mostly about the double presentation since both the EU and its Member States have been formally represented within the WTO system. At that point, it should be reminded that the decisions within the WTO system are taken by consensus though there is a WTO decision-making procedure. Thus, those critics seem to be undue criticisms mostly asserted by the US (Mortensen, 2009: 82).

\subsection{EU within the Multilateral Trading System: GATT 1947 Years}

The founding members of the EU have been the active participants of the multilateral trading system since the entering into force of GATT in 1948. However, it should be remarked that the EU was not a contracting party by itself at the GATT 1947 process until it has gained a legal status and has become an international organization with the birth of its successor, WTO.

Actually, the origins of the multilateral trading system for the founding members of the EU dates back to the establishment of the Organization for European Economic Cooperation (OEEC). The OEEC came into being in 1948 as a permanent international 
Issue no. $27 / 2018$

organization which would administer the US financial aid program for the re-construction of the post-war European economies.

Among the promotion of cooperation for the economic recovery of Europe and related collaboration aims, there were goals of reducing tariffs and non-tariff restrictions for the expansion of trade. As such, the OEEC was not only a part of the multilateral trading system but also a basis of the European integration. Even though, the OEEC worked in conjunction with the GATT 1947 in reducing the impediments on the free movement of goods, its success was very limited (Urwin, 1991: 21). In other words, free trade distortions maintained at the OEEC times.

The founding members of the EU were also taking part at the OEEC which became the Organization for Economic Cooperation and Development (OECD) afterwards. Thus, at the beginning of the 1950s, the six founding members were actively participating within the GATT and laying the foundations of a deeper economic integration alongside the OEEC experience.

In the early years of GATT 1947, the internal interests of the EU dominated the EU's acts and behaviors within the multilateral trading system. The EU's multilateral trading position was shaped by its internal trade priorities. Thus, conflicting interests were appeared within the multilateral trading system. It should be acknowledged that most of the EU's controversies within the multilateral trading system was arising due to the trade conflicts between the EU and the US. In the early years of GATT 1947, trade restrictions became one of the main controversies between the EU and the US. In 1950s, both parts could not agree on the balance of trade concessions because both sides preferred the protectionist status quo (Dür, 2008: 655).

Moreover, the US exporters were worrying about a probable trade diversion effect of the establishment of the EU. According to Piquet, Kreinin and Benoit, the US exports of electrical and industrial machinery, machine tools, certain chemicals and cars would likely suffer from trade diversion (Piquet, 1958: 133; Kreinin, 1959: 618; Benoit, 1961: 172). This so-called neo-mercantilist attitude of the EU has been more or less tolerated by the US. However, the same tolerance was not given when the matter comes to the Common Agricultural Policy (CAP) of the EU. The CAP was one of the most protectionist policies of 
Issue no. $27 / 2018$

the world economy which has ever seen. In spite of the complaints and the claims of the US as well as the other GATT 1947 signatory states, the EU achieved to fend off the demands for agricultural market liberalization in 1960s. Thus, at the trade negotiations under the auspices of the Kennedy Round in 1960s, the EU was discerned as a self-defendant GATT party.

The EU's self-defensiveness was not changed so much during the Tokyo Round of trade negotiations in 1970s. This time there were the non-tariff restrictions on the negotiation table and the GATT 1947 was weak and insufficient in combatting with these new type of protectionist measures. Fortunately, there appeared a policy shift within the EU from selfdefendant status to a more compatible attitude with the multilateral trading system in 1980s. Consequently, the Uruguay Round of trade negotiations which was started in 1996 finalized in 1994, giving birth to an international organization, the WTO, responsible from the wellfunctioning of the multilateral trading system.

\section{4. $\quad$ EU within the Multilateral Trading System: WTO Years}

The WTO was born after an eight years of birth pangs at the Uruguay Round of trade negotiations. The EU acted together with the US on the inclusion of the services (LealArcas, 2007: 369) and intellectual property rights to the WTO mechanisms. Agricultural trade and the CAP as a whole have continued to be problematic but the successes on the GATS and TRIPS have undermined the negative effects of the agriculture issue.

After the establishment of the WTO, the EU had become a more active and enthusiastic participant of the multilateral trading system. The EU had tried to put the labor standards, environmental issues, public procurement and competition rules on the WTO agenda. At the First WTO Ministerial Conference which was held in December 1996 in Singapore, the EU gave a priority to the trade and investment, trade and competition policy, transparency in government procurement and trade facilitation subjects, referred to Singapore Issues. Although there was not a concrete step towards their implementation, Singapore Issues entered into the agenda of the WTO with the WTO Singapore Ministerial Conference.

Soon after the Uruguay Round, the EU promoted to launch a new round of trade negotiations in 1999 called Seattle Round. Nevertheless, Seattle Round is recognized with the street protests of the anti-globalization activists not with the achievements on the trade negotiations. The oppositions were mainly on the furthering of the trade liberalization 
Issue no. $27 / 2018$

through new subordinating issues like environment, working conditions, commodity standards which were mostly encompassing the Singapore Issues.

However, the Seattle Round failure was almost a stimulus for the EU in engaging with the multilateral trading issues. Former EU Commissioner, Sir Leon Brittan proposed to start up a new round of trade negotiations which was called Millennium Round (Jonquieres, 1999: 2). According to the EU, this new round of trade negotiations had to be initiated by 2000 .

Consequently, the new round of trade negotiations begun in November 2001 in Doha with an agenda incorporating a special emphasis to economic development. Thus, this new round of trade negotiations is referred to Doha Development Round and its scope is called Doha Development Agenda (DDA). Singapore Issues were subordinated at the Doha Round, paving the way to the economic development issues and vulnerabilities of the least developed and developing economies. Next to the Singapore Issues, the DDA became the one of the most important trade priorities of the EU in 2000s.

Unlike the other round of trade negotiations, the main promoter of the Doha Round was the EU. In all the previous GATT negotiation rounds, the primary inducer was the US. In that sense, Doha Round has a very special and significant importance for the EU. Former EU Commissioner Pascal Lamy defined the EU's general priorities in the DDA as better access to markets, further liberalization of agriculture, giving developing countries a better deal, protection of the environment, better international governance and promotion of sustainable development at a conference with representative of civil society organized by the Cercle Européen of Confrontations in Brussels. (Lamy, 2001). It is explicitly understood that the EU did not give up to pursue its prospects for Singapore Issues but added to them an economic and sustainable development dimension at all.

Actually, the development emphasis of the Doha Round was supported by the need to address the economic development asymmetries of the WTO Member States and to induce the developed countries to open up their markets to the exports of the least-developed and developing countries. In one hand, this development emphasis was in conformity with the EU's sustainable development strategies. On the other hand, the implications of a development round were uncertain and ambiguous for the US (Ahnlid, Elgström, 2014: 81). 
Issue no. $27 / 2018$

Despite an ambitious start up, the Doha Ministerial Conference put off almost all the subjects to the next Ministerial Conference, scheduled in 2003. The reason of this postponement was a general disagreement among the WTO Member States on the future agenda of the WTO. However, disagreement sustained at the Cancun Ministerial Conference which was held in 2003 and the negotiations on the DDA collapsed due to a robust NorthSouth debate on the agricultural issues. The most uncompromising Northern counterparts were the EU and US. On the other part of the debate, there were the Southern least-developed and developing counterparts whose demands were mostly rejected by the Northern. Moreover, the Southern countries did not accept a deal which they regarded unfavorable and established two different country groups within the negotiation process, namely the G-20 and G-90 countries. The G-20 countries were the middle-income developing countries while the G-90 constituted poorer developing countries (Leal-Arcas, 2007: 380).

The Cancun Ministerial Conference has constituted a stumbling stone for the multilateral trading system from two important aspects. The first aspect is that the everincreasing crisis on the legitimacy of the WTO was explicitly revealed for the first time at the Cancun Ministerial Conference. The second aspect is the country gatherings. The WTO member countries formed country groups so as to speak in one voice at the issues in which they have common concern. From Cancun Ministerial Conference on, it is understood that it would not be easy to reach a consensus on a WTO issue. That's because of the conflicting interests of the WTO member countries and lack of a common WTO-wide concern. This is actually a fact stemming from a growing asymmetry among the WTO member countries.

Following the failure of the Cancun Ministerial Conference, the WTO Members agreed on a framework in July 2004, referred to July 2004 Package, to keep the DDA alive. The July 2004 Package focused on five priority areas, namely agriculture, non-agricultural market access (NAMA), development, trade facilitation and services. Regarding the intellectual property, environment and the other related issues, the Package emphasized the importance of the negotiation process, leaving them to an unknown procedure (WTOc).

July 2004 Package paved the way to the Hong Kong Ministerial Conference in 2005. Agriculture was the main fault line among the WTO members as well as NAMA and services issues. Groups of countries continued to dominate the negotiations. Ad hoc groups of 
countries come together on specific issues. At the end, a slow but solid progress was achieved (Wilkinson, 2006: 292).

As of January 2018, five Ministerial Conferences were held following the Hong Kong Ministerial Conference, being the Buenos Aires Ministerial Conference latest in December 2017 (WTOd). In each of the Conferences, the WTO members proclaimed their commitments regarding the DDA without any worthwhile progress. Consequently, the multilateral trading system is not at a deadlock but going at a snail's pace.

Although the EU has been the main promoter and introducer of the Doha Round of trade negotiations and the DDA itself, the status-quo is not satisfactory in terms of its prospects and far from its expectations. Singapore Issues have been left behind without any concrete steps. Agricultural issues and the NAMA have preceded trade and investment, trade and competition policy, transparency in government procurement and trade facilitation subjects.

It'd be appropriate to end up this part with the words of the EU Trade Commissioner Cecilia Malmström who evaluated the outcomes of the latest Buenos Aires Ministerial Conference: All WTO members have to face a simple fact: we failed to achieve all our objectives and did not achieve any multilateral outcome. The sad reality is that we did not even agree to stop subsidizing illegal fishing (European Commission, 2017a).

\section{EU's New-Age Partnerships within the New External Trade Policy}

As we have briefly examined, the EU has been an active partner of the multilateral trading system since GATT 1947. Despite some tough agricultural trade conflicts arising mainly from the CAP, the EU had never given up to rely on the procedures and implementations of the multilateral trading system. Nevertheless, it hasn't relinquished to conduct its own preferential trade relations with the countries all over the world. Actually, the EU's preferential trade relations are compatible with the Article XXIV of the GATT which lets the WTO members to conduct preferential trade relations, providing the conditions defined at the Article.

The EU has established various forms of preferential trade relations with numerous countries in different geographies. They are mostly in the form of preferential trade 
Issue no. $27 / 2018$

agreements (PTA), free trade areas (FTA) and customs unions (CU). These different forms of preferential trade relations constitute petit trade regimes that link countries in various ways (Panezi, 2016: 1). Those discrepant trading links resemble a spaghetti bowl as Bhagwati has suggested (Bhagwati, 1995).

Even though the examination of the preferential trade relations of the EU is out of the scope of this study, a brief summary would be adequate. It should be mentioned that the EU has given priority to the developing countries which had once colonial relations with some Member States. These are referred to African Caribbean and Pacific (ACP) countries and have been enjoying a special trade regime that enables unilateral trade preferences to them. Mediterranean countries have also been privileged trade partners of the EU though a sufficient policy outcome has not attained so far. The EU started Everything But Arms (EBA) initiative in 2001 for the least-developed countries to let their exports to access to the EU market duty-free and quota-free. Apart from them, there has been a Generalized System of Preferences (GSP) for the least-developed and developing countries since 1971. These constitute examples of the EU's preferential trade relations with mostly the least-developed and developing countries with a special emphasis of mentoring for their economic development.

On the other hand, the EU has established a very special relationship with Turkey. This relationship not only covers trade but also a prospect for full membership of Turkey to the EU when the required conditions are met. A customs union between the parties was achieved in 1996 on the industrial commodities and accession negotiations for the full membership of the EU were initiated in 2005. Turkey has been on the enlargement agenda of the EU with its candidacy status. Next to Turkey, Albania, the Former Yugoslav Republic of Macedonia, Montenegro and Serbia are the other candidate countries for the full membership of the EU.

Until now, the preferential trade relations of the EU with the least-developed and developing countries were briefly mentioned. Apart from them, the EU has also conducted preferential trade relations with the developed countries. Among them, trade relations with the US deserve a more detailed explanation. Despite a long history between the EU and the US, trade relations were strengthen within the Cold War era. After the II. World War, the US 
Issue no. $27 / 2018$

acted as a mentor towards Europe in its reconstruction and fast economic recovery via Marshall Plan. Establishment of the economic integration within Europe speeded up the economic recovery. Soon after the establishment of the EU, trade dispute appeared between the parties arising from trade protectionism. Trade disputes which were mainly on the agricultural issues had continued until 1990s. Then, initiatives for a closer and solid economic cooperation started not only to prevent the accelerated trade disputes between the parties but also to offset the negative welfare effects of protectionism on the world economy as a whole (Dağdemir, 2014: 32).

After a long lasting preparatory efforts and an ambitious negotiation process, a more vigorous relationship, referred to Transatlantic Trade and Investment Partnership (TTIP) was launched in July 2013. TTIP negotiations cover market access for agricultural and industrial commodities, government procurement, investment, energy and raw materials, regulatory issues, services, intellectual property rights, competition, dispute settlement, small and medium-sized enterprises, sustainable development, customs/trade facilitation and state owned enterprises (European Commission, 2013). When the scope of the TTIP negotiations are examined, it is explicitly understood that they are more than the Singapore Issues.

Despite an accelerated start up, the negotiations for the TTIP has been slowed down together with the new US administration. The parties denoted their commitments to the success of the TTIP at latest negotiation round which was held in October 2015. Though taking a back seat, the TTIP has still been on the privileged agenda of both the EU and the US.

Alongside with the TTIP, the EU has initiated new trade agreements with Canada, Japan and South Korea. The EU's new trade agreement with Canada is referred to Comprehensive Economic and Trade Agreement (CETA). The EU and Canada Joint Ministerial Committee Under the Strategic Partnership Agreement was met on 4 December 2017 and reaffirmed a joint commitment to a progressive free and fair trade agenda and fight against protectionism (EU-Canada Joint Ministerial Committee). Moreover, CETA has commitments to promote labor rights, environmental protection and sustainable development.

Regarding Japan, the EU finalized the EU-Japan Economic Partnership Agreement (EPA) at the end of 2017. The EPA has been aiming not only to remove trade barriers but 
also to deal with protecting the environment, tackling climate change, securing access to energy supplies and ensuring regional stability (European Commission, 2017b). According to the EU Trade Commissioner Malmström; the EU and Japan share a common vision for an open and rules-based world economy that guarantees the highest standards. The EU and Japan are sending messages to other countries about the importance of free and fair trade and of shaping globalization (European Commission, 2017c).

Another new-age partnership was concluded with South Korea. The EU-South Korea Free Trade Agreement has been provisionally applied since July 2011 and was formally ratified in December 2015 (Official Journal of the EU, 2011). Within the scope of this agreement, there have also been common regulations on services, investment, competition, government procurement, intellectual property rights, transparency in regulation and sustainable development as well as the elimination of the trade restrictions.

All these new-age partnerships are embodied in the new external trade policy of the EU. Actually, they have constituted the roots of the new policy which was launched by the Trade for All Strategy in 2015. In other words, they were merely predecessors of the new external trade policy of the EU.

\section{EU's New-Age Partnerships within the Multilateral Trading System}

The EU has entered into the 2010s with various unpleasant formidable issues surrounding and embracing itself. Negative effects of the global financial crisis emanated from the US has still been affecting the EU economy. The legitimacy of the Euro as a single currency and the effectiveness of the Euro-Zone has been ambiguous. There have been hesitations on the deepening and widening of the EU. The EU has met a Brexit fact which should be tackled after the decision of the United Kingdom to exit from the full membership. Amidst all these unfavorable context, the EU has been trying enthusiastically to strengthen its external trade policy.

Certainly, the deadlock of the DDA has accelerated the efforts of the EU in designating and updating its external trade policy. The EU's launching its new external trade policy and coming to a halt within the multilateral trading system cannot be explained as a simple coincidence. It should be remembered that the EU has been pro-active in shaping or 
updating its trade relations with leading economies of the world, namely the US, Canada, Japan and South Korea since the beginning of 2010s. Yet, the announcement of the new external trade policy of the EU, referred to Trade for All Strategy was in 2015. All these developments prove that there has been a renovation within the external trade policy of the EU that was begun in the first half of 2010s.

Actually, the new-age partnerships of the EU initiated mainly with the US, Canada, Japan and South Korea have given the signals of the new external trade policy of the EU. These partnerships are more beyond than the EU's conventional preferential trade agreements because they mostly cover services, investment, environment, intellectual property rights, public procurement, competition rules, etc. simply once the EU had tried to incorporate within the multilateral trading system.

Then, here comes the baffling question: Qua Vadis external trade policy of the EU? By looking at the new-age partnerships initiated at the first half of $2010 \mathrm{~s}$, it is evident that the EU would not just like to stand still within the multilateral trading system waiting for its revival. If this is the case, then, would the EU like to export its own values on to the world trade and surpass the multilateral trading system?

Essentially, there has been a common perception within the literature that the EU exports its own regulations, merits and values to the world via its preferential trade relations. The studies of Meunier and Nicolaïdis (2006: 907), García (2013: 535), Müller and Falkner (2014: 11-12), Young and Peterson (2014: 183) regard the EU as a global actor which has been promoting its own values. Actually, the EU is strengthening this perception on its own terms. The EU Trade Commissioner Malmström announced in its forward to the Trade for All Strategy that the new external trade policy would not project only the interests of the EU but also its values (European Commission, 2015).

However, these perceptions are mostly about the preferential trade relations of the EU with the least-developed or developing countries which constitute a hub-and-spoke type of bilateralism. It is a common view of all that the EU has been trying to be a political and economic mentor to the vulnerable countries by exporting its own values. Yet, preferential trade relations have always been the main instrument of the EU in its mentoring. 
Issue no. $27 / 2018$

Nonetheless, it is hard to assert and believe that EU has been pretending to export its own values and merits to the leading economies of the world, like the US, Canada, Japan and South Korea. Even though the scope of the new-age partnerships is very broad, it would be very hard to reconcile these new-age partners on such generous embrace without their consent. Thus, it might be postulated that the EU together with its new-age partners would like to sustain its global acting in external trade as well as in a wide range of issues related with external trade.

Then, another essential question arises: In its global acting, would the EU by-pass the multilateral trading system or commit itself with it as a point-guard ${ }^{1}$ ? A probable answer could be extracted from the Trade for All Strategy. Though it claims to respect for the interests and the values of the EU, it also confirms the EU's commitment to a forwardlooking program of negotiations to shape globalization. Priority would most likely be given to the deadlocked DDA so as to give an impetus to the multilateral trading system which was lagging behind.

\section{Conclusion}

The EU has always been a leading actor of world economics. It has been playing a constructive role in well-functioning of the multilateral trading system since the signing of GATT. Together with the establishment of the WTO, the EU has tried to enhance its efficiency in conducting a new and forward-looking agenda for the multilateral trading system. It has endeavored to incorporate investment, competition, government procurement and trade facilitation subjects, referred to Singapore Issues into the multilateral trading system. Next to these new subjects, it has promoted the DDA and tried hard to keep the negotiating countries on the table.

Alongside with the prominent role within the multilateral trading system, the EU has conducted its preferential trade relations with various countries. Most of the preferential trade relations of the EU have resembled to a hub-and-spoke type of bilateralism, allowing the EU to export its own values and merits for the economic and political stability of its partners.

\footnotetext{
${ }^{1}$ Point-guard is a basketball team's best ball handler and passer. Thus, he/she leads his/her team in assists and steals.
} 
Issue no. $27 / 2018$

However, it would be fallacious to denominate the new-age partnerships of the EU which were launched with the US, Canada, Japan and South Korea within the same category. Instead, the EU has been pretending to regulate new trade-related issues with its new-age partners.

The new-age partnerships have been initiated soon after the deadlock of the DDA and shouldn't be regarded as a basic coincidence. They were almost the messengers of the new external trade policy of the EU which was briefly expounded at the Trade for All Strategy. It would be adequate to interpret all these new initiatives of the EU as efforts to maintain the multilateral trading system on the track which has deadlocked for more than a decade. Consequently, it wouldn't be wrong to postulate that the EU would like to be the point-guard within the multilateral trading system in facing global challenges together and designating multilateralism for the benefit of all.

\section{References}

- AHNLID, A., ELGSTRÖM, O. (2014) "Challenging the European Union: The Rising Powers and the USA in the Doha Round", Contemporary Politics, 20 (1), 77-89.

- BENOIT, E. (1961) Europe at Sixes and Sevens: The Common Market, the Free Trade Association and the United States, New York: Colombia University Press.

- BHAGWATI, J. (1995) “US Trade Policy: The Infatuation with Free Trade Agreements", BHAGWATI, J., KRUEGER, A. (eds), The Dangerous Drift to Preferential Trade Agreements, Washington DC: AEI Press.

- BOURGEOIS, J. H. J. (2000) "The European Court of Justice and the WTO: Problems and Challenges", WEILER, J. H. H. (ed), The EU, WTO and NAFTA: Towards a Common Law of International Trade? Oxford: Oxford University Press, 71-124.

- DAĞDEMIR, U. E. (2014) "From Economic Protectorate to the Transatlantic Trade and Investment Partnership: A New-Age Relationship between the European Union and the United States?", Marmara Journal of European Studies, 22 (1), 31-63.

- DÜR, A. (2008) "Bargaining Power and Trade Liberalization: European External Trade Policies in the 1960s", European Journal of International Relations, 14 (4), 645-669. 
Issue no. $27 / 2018$

- EU-CANADA

JOINT

MINISTERIAL

COMMITTEE

(2017)

http://www.consilium.europa.eu/media/32024/20171204-joint-statement.pdf (Retrieved on: January 15,2018$)$.

- EUROPEAN COMMISSION (2013) EU and US Conclude First Round of TTIP Negotiations in Washington, http://europa.eu/rapid/press-release_IP-13-691_en.htm (Retrieved on: December 4, 2013).

- EUROPEAN COMMISSION (2015) Trade for All: Towards a More Responsible Trade and Investment Policy, http://rade.ec.europa.eu/doclib/docs/2015/october/tradoc_153846.pdf (Retrieved on: November 17, 2017).

- EUROPEAN COMMISSION (2017a) WTO Meeting in Buenos Aires: A Missed Opportunity, http://trade.ec.europa.eu/doclib/press/index.cfm?id=1772 (Retrieved on: January 11, 2018).

- EUROPEAN COMMISSION (2017b) A New EU Trade Agreement with Japan, http://trade.ec.europa.eu/doclib/docs/2017/july/tradoc_155684.pdf (Retrieved on: January $15,2018)$.

- EUROPEAN COMMISSION (2017c) EU and Japan Finalise Economic Partnership Agreement, Press Release, 8 December, http://europa.eu/rapid/press-release_IP-175142_en.htm (Retrieved on: January 15, 2018).

- GARCÍA, M. (2013) "From Idealism to Realism? EU Preferential Trade Agreement Policy", Journal of Contemporary European Research, 9 (4), 521-541.

- JONQUIERES, de G. (1999) "World Trade 2: Tentative Embrace of the Open Market: The European Union", Financial Times: London, 29 November.

- KREININ, M. E. (1959) "European Integration and American Trade", The American Economic Review, 49 (4), 615-627.

- LAMY, P. (2001) "Issues and Strategy for a New WTO Round of Multilateral Negotiations", Commissioner Lamy Speech, 27 September 2001, http:/trade.ec.europa.eu/doclib/docs/2004/october/tradoc_119485.pdf (Retrieved on: January 9, 2018). 
Issue no. $27 / 2018$

- LEAL-ARCAS, R. (2007) The Resumption of the Doha Round and the Future of Services Trade", Loyola of Los Angeles International and Comparative Law Review, 29 (3), 339461.

- MEUNIER, S., NICOLAÏDIS, K. (2006) "The European Union as a Conflicted Trade Power", Journal of European Public Policy, 13 (6), 906-925.

- MORTENSEN, J. L. (2009) “The World Trade Organization and the European Union”, JORGENSEN, K. E. (ed), The European Union and International Organizations, London and New York: Routledge, 80-100.

- MÜLlER, P. and FALKNER, G. (2014) “The EU as a Policy Exporter? The Conceptual Framework", MÜLLER, P., FALKNER, G. (eds), EU Politics in a Global Perspective: Shaping or Taking International Regimes? London: Routledge, 1-19.

- OECD Web Site http://www.oecd.org/general/organisationforeuropeaneconomiccooperation.htm (Retrieved on: December 5, 2017).

- OFFICIAL JOURNAL OF THE EUROPEAN UNION (2011) Free Trade Agreement between the European Union and its Member States, of the One Part and the Republic of Korea, of the Other Part, L127/6, 14.5.2011.

- PANEZI, M. (2016) "The WTO and the Spaghetti Bowl of Free Trade Agreements", CIGI Policy Brief, 87, September.

- PIQUET, H. S. (1958) "First Effects of the Common Market: The Impact of Changing Tariffs on US Exports", The European Common Market: New Frontier for American Business, New York: American Management Association, 124-159.

- PISCHEL, G. (2001) "Trade, Treaties and Treason: Some Underlying Aspects of the Difficult Relationship between the EU and the WTO", European Foreign Affairs Review, $6(1), 103-133$.

- URWIN, D. W. (1991) The Community of Europe: A History of European Integration Since 1945, London and New York: Longman.

- YOUnG, A. R., PETERSON, J. (2014) Parochial Global Europe: $21^{\text {st }}$ Century Trade Politics, Oxford: Oxford University Press. 
Issue no. $27 / 2018$

- WILKINSON, R. (2006) "The WTO in Hong Kong: What It Really Means for the Doha Development Agenda", New Political Economy, 11 (2), 291-304.

- WTOa, Web Site, Understanding the WTO https://www.wto.org/english/thewto_e/whatis_e/tif_e/fact2_e.htm (Retrieved on: January $3,2018)$.

- WTOb, Web Site, https://www.wto.org/english/docs_e/legal_e/10-24.pdf (Retrieved on: January 3, 2018).

- WTOc, The July 2004 Package https://www.wto.org/english/tratop_e/dda_e/dda_package_july04_e.htm (Retrieved on: January 10, 2018).

- WTOd, Ministerial Conferences https://www.wto.org/english/thewto_e/minist_e/minist_e.htm (Retrieved on: January 11, 2018). 